\title{
Amaryllis belladonna L. (Amaryllidaceae, Amaryllidoideae), first record as naturalized geophyte in Tunisia and continental North Africa
}

\author{
Ridha El Mokni $i^{1,2,3}$ (i) , Salvatore Pasta ${ }^{4}$ (i) \& Davide Pacifico 4 (i)
}

Key words: New records, Aliens, Bulbs, Sejnane, North Africa.

Ključne besede: novi zapisi, tujerodne vrste, čebulice, Sejnane, Severna Afrika.

Received: 31. 3. 2020

Revision received: 29. 5. 2020

Accepted: 2. 6. 2020

\begin{abstract}
Amaryllis belladonna L. is recorded for the first time as a naturalized non-native geophyte new to Tunisian and continental North African flora. Additional information on its current distribution and habitat, a brief morphological description, as well as some taxonomic notes, are provided.
\end{abstract}

Izvleček

Amaryllis belladonna L. je prvič zabeležena kot naturalizirani tujerodni geofit, nov za tunizijsko in celinsko severnoafriško floro. Predstavljene so dodatne informacije o trenutni distribuciji in habitatu, kratek morfološki opis, kot tudi nekaj taksonomskih zapiskov.

1 University of Jendouba, Laboratory of Silvo-Pastoral Resources, Silvo-Pastoral Institute of Tabarka, BP. 345, Tabarka 8110, Tunisia.

2 University of Monastir, Laboratory of Botany, Cryptogamy and Plant Biology, Department of Pharmaceutical Sciences "A", Faculty of Pharmacy of Monastir, Avenue Avicenna, 5000-Monastir, Tunisia. Email: riridah@hotmail.com

3 University of Carthage, IRESA, Laboratory of Forest Ecology, INRGREF, BP. 10, Ariana 2080, Tunisia.

4 Institute of Bioscience and BioResources (IBBR), Research Council (CNR), Unit of Palermo, Corso Calatafimi 414, 90129 Palermo, Italy. 


\section{Introduction}

Extensive botanical surveys have been carried out by the first author between the years 2010 to 2020 and allowed to update and improve the botanical knowledge about Tunisian flora (e.g. El Mokni et al. 2010, El Mokni \& El Aouni 2011, El Mokni et al. 2012, 2013a, 2013b, 2014, 2015a, 2015b, 2015c, El Mokni \& Iamonico 2017, 2018a, 2018b, 2019, El Mokni \& Verloove 2019, El Mokni \& Domina 2019, 2020, El Mokni 2018, 2020, Domina \& El Mokni 2019). During one of these field surveys in 2016 a naturalized population of Amaryllis L., previously non recorded in the country, was found.

Amaryllis L. is the only genus in the subtribe Amaryllidinae, tribe Amaryllideae (Brenzel 2001). It is a small genus of flowering bulbs, with only two species $(A$. belladonna L. and $A$. paradisicola Snijman). In particular, A. belladonna $\mathrm{L}$. is native to the Western Cape region of South Africa (Bond \& Goldblatt 1984). This species occurs as a naturalized alien in several Mediterranean countries, where its degree of invasiveness is reported with "status unknown" (WCSP 2020). As for North Africa, the species has been previously reported only for the Canary Islands (Dobignard \& Chatelain 2011, WCSP 2020, APD 2020). Our finding represents the first record for Tunisia and continental North Africa where it was found as naturalized in the Sejnane region (Northern Tunisia). This paper provides additional information on the naturalized population, as well as a review on the global distribution and ecology of the species. Moreover, a detailed morphological description of the plant, supported by numerous detailed photographs, is provided.

\section{Material and methods}

The present work is based on field botanical surveys carried out by the first author (REM) in Northern Tunisia (North Africa), going with analysis of relevant literature and data about both known species of the genus (A. belladonna L. and A. paradisicola Snijman) available at https://www.wikizero.com/en/Amaryllis\#cite_noteBiodiveristyexp-2 and https://www.wikizero.com/en/ Amaryllis_paradisicola and personal collection of the first author (REM) which is deposited in the Herbaria of the Faculty of Pharmacy of Monastir (not yet listed in Index Herbariorum, Thiers 2020). The description is in part original based on direct observations of Tunisian specimens.

\section{Research area}

The Sejnane area belongs to the Mogods Hills (Northern Tunisia), at the eastern boundary of the region KabyliaNumidia- Kroumiria, recently shown to constitute a high hotspot of plant diversity within the Mediterranean basin (Véla \& Benhouhou 2007). Its eroded hills are made of nummulitic sandstone and culminating around $400 \mathrm{~m}$ a.s.l. From a geologic point of view the area is mostly characterized by a succession of reddish sandstone and silty clays (Crampon 1971). Each sandstone horizon is approximately $100 \mathrm{~m}$ thick and consists of fine to medium-grained sand with some lenses of coarse conglomerate (250-300 $\mathrm{mm}$ in diameter). The interbedded clayey layers are generally greenish to greyish in colour and about $300 \mathrm{~mm}$ thick (Castany 1953, Rouvier 1977). The mean annual rainfall is comprised between 600 and $900 \mathrm{~mm}$ in the plains and reaches $1200 \mathrm{~mm}$ on the surrounding hills (Dimanche \& Schoenenberger 1970). The woody vegetation of the Sejnane region is dominated by patches of degraded and discontinuous woodland dominated by cork oak woods (Quercus suber L.), intermingled with many other woody species typical to maquis and garrigue communities, such as Erica arborea L., Arbutus unedo L., Pistacia lentiscus L., Myrtus communis L., Cistus salviifolius L., C. monspeliensis L., Lavandula stoechas L. Many species of Eucalyptus have been planted in the region, mostly for beekeeping purposes.

\section{Results and discussion}

A population counting more than one hundred individuals was observed growing wild over an area of about $100 \mathrm{~m}^{2}$ together with several thermo-xerophilous herbs and grasses forming the undergrowth of a plantation of Cupressus sempervirens $\mathrm{L}$.

Morphological description based on living plants (Figure 1): The plant has large brownish bulbs $5-10 \mathrm{~cm}$ in diameter (Figure 1-A) and bears long, distichous, bright green leaves of $30-50(-60) \mathrm{cm}$ long and about $2-3 \mathrm{~cm}$ in width. The basal tuft of leaves can spread over $60 \mathrm{~cm}$, when bulb is divided. Each bulb produces one or two leafless stems, red-brown (Figure 1-B), up to $75 \mathrm{~cm}$ high with ca. 2-12 crown flowers in its top. Flowers are trumpet-shaped with pink-lilac or white with crimson-veined tepals, somehow recalling Lily flowers' (Figure 1-D), generally slightly bent towards the sun (Figure 1-C); corollas are about $6-10 \mathrm{~cm}$ long and $3-8 \mathrm{~cm}$ wide.

Phenology: flowering starts in September whilst fruiting time ends at November. 

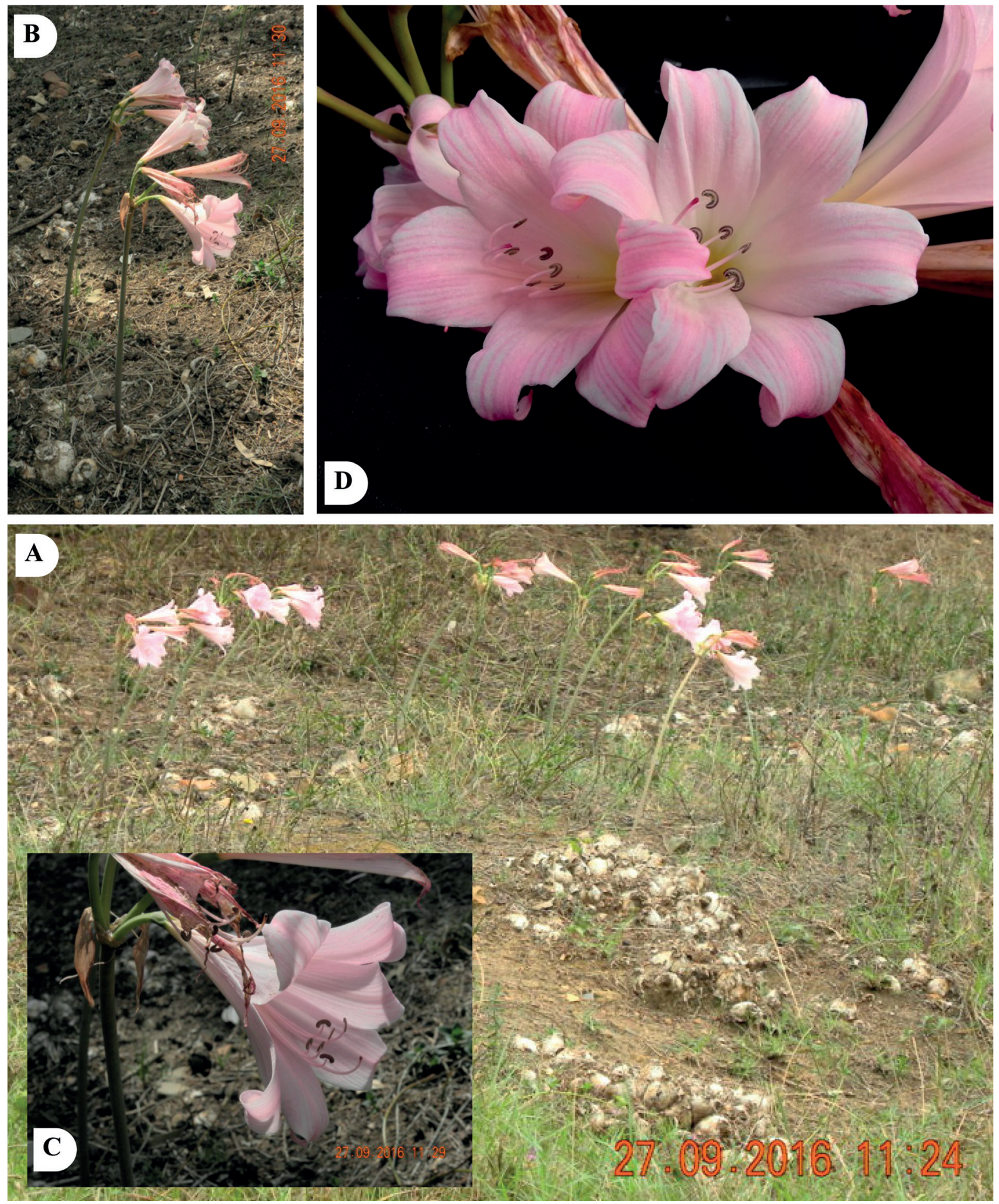

Figure 1: A) Amaryllis belladonna L. in its habitat with flowering stems emerging from the bulbs of the extended population (Sejnane region, Northern Tunisia), B) habit of the Belladonna Lily, C) detail of a pedicellate flower (lateral view), D) detail of flowers with pink-lilac tepals and medifixed anthers (top view). Photo credits: R. El Mokni (27.09.2016).

Slika 1: A) Amaryllis belladonna L. v svojem habitatu s cvetočimi stebli, ki izhajajo iz čebulic v proučevani populaciji (regija Sejnane, Severna Tunizija), B) habitus vrste Amaryllis belladonna, C) detajl cveta (stranski pogled), D) detajl cvetov z roza-lilastimi perionovimi listi in prašniki (pogled od zgoraj). Fotografija: R. El Mokni (27.09.2016). 
Native habitat and distribution range (Figure 2): A. belladonna is endemic to the Western Cape region of South Africa, being particularly common on the rocky southwest area between the Olifants River Valley and Knysna (Bond \& Goldblatt 1984). A. belladonna has been widely cultivated outside its natural habitat in several countries all over the world due to its ornamental value and responding to its climate needs (Johnson \& Snijman 1996). In fact, the over-wintering foliage is not frosttolerant; moreover, flowering in this species is strictly dependent on a dry resting period between leaf growth and flower production (Johnson \& Snijman 1996). The species has become naturalized in many temperate countries, including the Mediterranean Basin, where it is reported for Portugal and Corse (WCSP 2020), Western and Southern Australia, California and New Zealand (Duncan 2004) where it is locally escaped from abandoned gardens and cut-flower cultivations (Duncan et al. 2016) and as casual to locally naturalized in Italy (cf. Galasso et al. 2018).
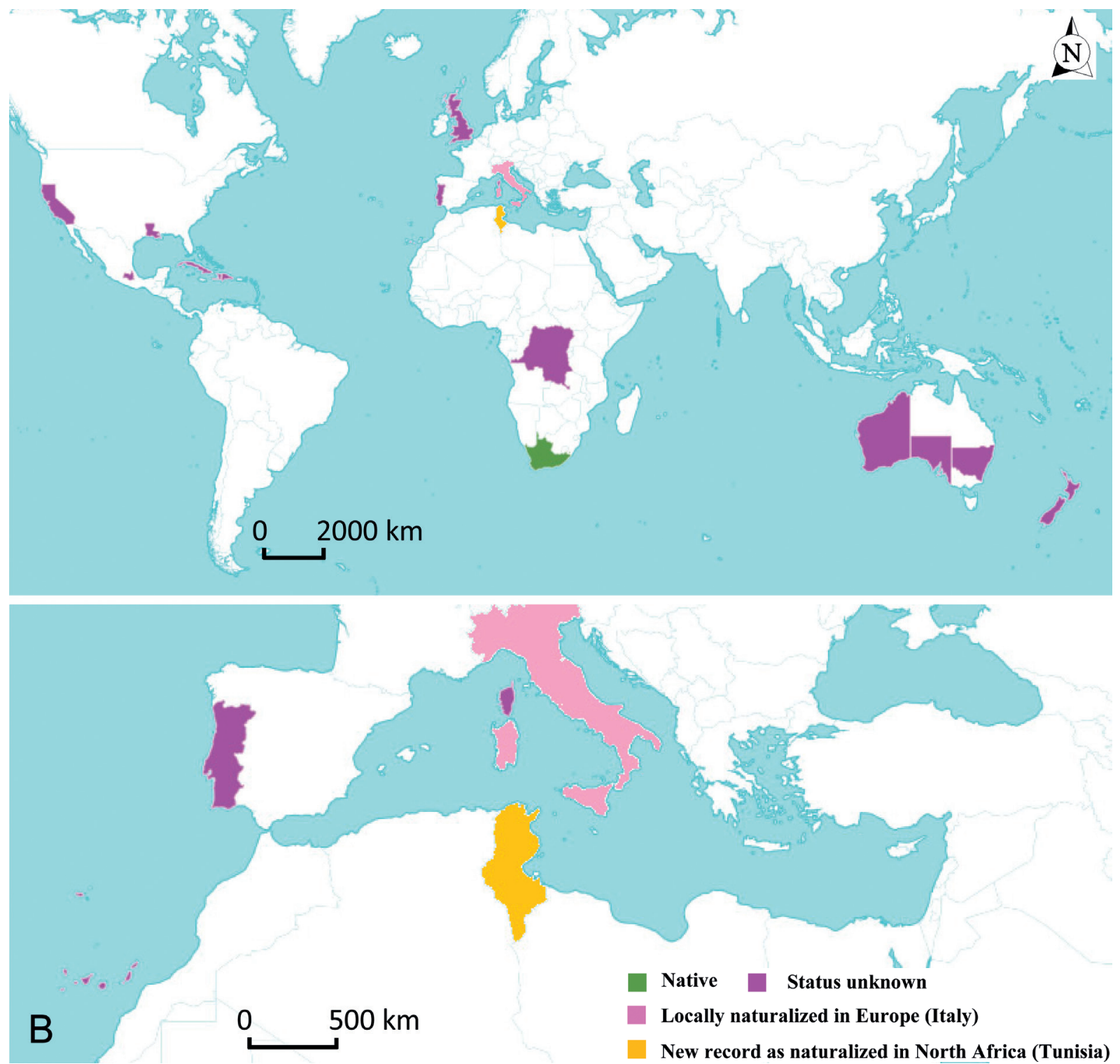

Figure 2: Current distribution range of Amaryllis belladonna L. with new localities in Tunisia, North Africa: A) global range, B) occurrence in Mediterranean countries (from http://plantsoftheworldonline.org/taxon/urn:lsid:ipni.org:names:62705-1, modified).

Slika 2: Trenutna razširjenost vrste Amaryllis belladonna L. z novimi nahajališči v Tuniziji, Severna Afrika: A) globalna razširjenost, B) pojavljanje v Sredozemlju (od http://plantsoftheworldonline.org/taxon/urn:lsid:ipni.org:names:62705-1, spremenjeno). 


\section{Nomenclatural remarks}

Amaryllis belladonna L., Sp. Pl.: 293. 1753 三 Coburgia belladonna (L.) Herb., Bot. Mag. 47: t. 2113 (1819) 三 Leopoldia belladonna (L.) M. Roem., Fam. Nat. Syn. Monogr. 4: 129 (1847)

Since its creation in 1753, the genus Amaryllis L. has been object of several taxonomic revisions. From 1938 to 1984, controversy ensued over the lectotypification of the name $A$. belladonna, type of the genus Amaryllis L., and thus involving a lively debate on the correct application of the Linnean generic name. Goldblatt (1984) and Meerow et al. (1997) reviewed the history of the controversy in detail. Despite prior general consensus that $A$. belladonna applies to the species from South Africa known as the Cape Belladonna (Dandy \& Fosberg 1954), Uphoff (1938) launched the contrary argument that the Linnean binomial must be applied to the neotropical south american Hippeastrum equestre Herb. [= H puniceum (Lam.) Kuntze]. This position was refuted by Sealy (1939). Uphoff $(1938,1939)$ insisted that Amaryllis should stand for Hippeastrum, and his position was defended by Traub and his supporters (Traub \& Moldenke 1949, Traub 1954, 1983, Tjaden 1979, 1981a, 1981b). Nomenclatural proposal supported by Jarvis (1984), and accepted at the $14^{\text {th }}$ International Botanical Congress held in 1987, that Amaryllis L. should be maintained, as a monotypic genus based on a specimen currently preserved in the Clifford Herbarium (the British Museum, Natural History). This specimen unquestionably represents the South African plant commonly known as the Cape Belladonna and agrees perfectly with Linnaeus definition of $A$. belladonna.

Taxonomic notes: Besides Amaryllis belladonna L., the genus Amaryllis includes $A$. paradisicola Snijman, a species described from the succulent Karoo (Northern Cape) discovered in the Richtersveld National Park (Snijman \& Williamson 1998).

Although these two species have large, trumpet-shaped flowers, $A$. paradisicola generally bears more flowers per inflorescence than $A$. belladonna, and its flower stems spread in all directions. In $A$. belladonna the leaves are narrow, longer and hairless while being much wider and covered with hairs (especially when young) than in $A$. paradisicola. The color of the flowers varies in many shades from pink to dark pink or almost burgundy, rarely pure white, always with a creamy yellow throat, which are generally strongly oriented on one side in $A$. belladonna, whereas the color of flowers of $A$. paradisicola are light pale pink to dark pink, without a creamy yellow throat. Moreover, $A$. belladonna shows longer stamens and a more deeply divided trifid stigma (Snijman \& Williamson 1998). In both species, the color of the flowers darkens with age and $A$. belladonna emits an overwhelming and sweet scent which intensifies at night, attracting the butterflies that visit them. The fragrance of flowers is much less intense in $A$. paradisicola.

Specimina visa: TUNISIA. Bizerta: Sejnane, Northern Tunisia, coordinates $37^{\circ} 04^{\prime} 03.84$ ” N, 0907’40.94” E, cooccurring together with several thermos-xerophilous herbs and grasses in the undergrowth of an evergreen cypress plantation, at c. $120 \mathrm{~m}$ a.s.l., 27 September 2016, R. El Mokni s.n. (Herb. El Mokni!), R. El Mokni s.n. (Herb. Univ. Monastir). Some bulbs were brought and cultivated at the Faculty of Pharmacy of Monastir (Univ. Monastir).

\section{Acknowledgements}

Thanks are due to all colleagues and friends of forestry service of Bizerta (Sejnane delegation) for their support and their help during field prospections.

Ridha El Mokni (D), https://orcid.org/0000-0003-3849-1039

Salvatore Pasta (D), https://orcid.org/0000-0003-3265-9072

Davide Pacifico (D), https://orcid.org/0000-0003-3620-9829

\section{References}

APD. 2020: African Plant Database (version 3.4.0). Amaryllis belladonna L. - Conservatoire et Jardin botaniques; South African National Biodiversity Institute, Pretoria Genève, viewed on 30 March 2020, from http://www.ville-ge.ch/musinfo/bd/cjb/africa/details. php?langue $=$ an\&id $=15978$

Bond, P. \& Goldblatt, P. 1984: Plants of the Cape Flora. Journal of South African Botany, 13 (Suppl.), pp. 1-455.

Brenzel, K. N. (ed.) 2001: Sunset western garden book. Menlo Park: Sunset Publishing. pp. 606-607.

Castany, G. 1953: Le Tyrrhénien de la région de Bizerte. Bulletin de la Société des Sciences Naturelles de Tunis VI:1952-1953.

Crampon, N. 1971: Étude géologique de la bordure des Mogods, du pays de Bizerte et du Nord des Hedil (Tunisie septentrionale). Thesis, Sci. Natur., Nancy I, tome 1, Stratigraphie, pp. 1-228.

Dandy, J. E. \& Fosberg, F. R. 1954: The type of Amaryllis belladonna L. Taxon 3: 231-232.

Dimanche, P., \& Schoenenberger, A. 1970: Description des milieux des Mogods et de Kroumirie. Tunis, Institut national de Recherches forestières, pp. 1-26.

Dobignard, A. \& Chatelain, C. 2011: Index synonymique de la flore d'Afrique du Nord. Conservatoire et Jardin botaniques, Ville de Genève, hors-série, vol. 2, p. 13.

Domina, G. \& El Mokni, R. 2019: An inventory of the names of vascular plants endemic to $C$ Mediterranean and described from Tunisia. Phytotaxa 409 (3): 105-128.

Duncan, G. 2004: Amaryllis magic. Veld \& Flora 90: 142-147.

Duncan, G., Jeppe, B. \& Voigt, L. 2016: The Amaryllidaceae of Southern Africa. Kew Publishing, pp. 1-709. 
El Mokni, R. 2018: Serapias xdebelairii, a new natural hybrid from Tunisia within a sympatric population of $S$. stenopetala and S. parviflora. Journal of European Orchids 50 (1): 67-80.

El Mokni, R. 2020: Echinophora spinosa L. (Apiaceae), a new species in the flora of Tunisia and second report from North Africa. Hacquetia 19(1): 137-142.

El Mokni, R., Amari, D. \& El Aouni, M. H. 2013a:

Two varieties of Ophrys apifera (Orchidaceae) new to North Africa. Journal Europäischer Orchideen 45(1): 77-89.

El Mokni, R., Domina, G., Sebei, H. \& El Aouni, M. H. 2015a: Taxonomic notes and distribution of taxa of Orobanche gr. minor (Orobanchaceae) from Tunisia. Acta Botanica Gallica 162 (1): 5-10.

El Mokni, R., Domina, G., Sebei, H. \& El Aouni, M. H. 2015b: On the distribution and subspecific variation of the Tunisian-Algerian endemic Delphinium sylvaticum Pomel (Ranunculaceae). Nordic Journal of Botany 33: 548-554.

El Mokni, R., Domina, G., Sebei, H. \& El Aouni, M. H. 2014: Hyacinthoides kroumiriensis sp. nov. (Hyacinthaceae): a new species from North West of Tunisia. International Journal of Advanced Research 2(9): 640-644.

El Mokni, R., El Mahmoudi, M. R. \& El Aouni, M. H. 2010: Neottia nidus-avis (L.) L. C. Rich.: une nouvelle orchidée pour la flore de la Tunisie. L'orchidophile 41 (3): 181-187.

El Mokni, R., Hamdi, N., De Belair, G. \& El Aouni, M. H. 2012: Découverte d'Ibicella lutea (Lindl.) Van Eselt. (Martyniaceae) en Kroumirie (Nord-Ouest de la Tunisie). Poiretia 4: 1-6.

El Mokni, R., Kasri, M. \& El Aouni, M. H. 2013b: Volkameria inermis (Lamiaceae) a new alien species naturalized to the Tunisian coast, first record for North-Africa. Flora Mediterranea 23: 117-122.

El Mokni, R., Sebei, H. \& El Aouni, M. H. 2015c: Rediscovery of a rare North African endemic Odontites (Orobanchaceae): first record and variability from Tunisia. International Journal of Advanced Research 3 (2): 376-382.

El Mokni, R. \& Domina, G. 2019: Taxonomic and distributive notes on Serapias lingua subsp. tunetana (Orchidaceae), a rare endemic to Tunisia. Collectanea Botanica 38: e005.

El Mokni, R. \& Domina, G. 2020: Additions to terrestrial flora of Tunisia: occurrence and taxonomic notes. Check List 16 (3): 553-561.

El Mokni, R. \& El Aouni, M. H. 2011: Découverte de Sparaxis tricolore, Sparaxis tricolor (Curt.) Ker-Gawl. (Iridaceae Juss.) pour la flore de Tunisie: une adventice naturalisée. Le Monde des Plantes 505: 11-14.

El Mokni, R. \& Iamonico, D. 2017: Alcea setosa (Boiss.) Alef. In RaabStraube, E. von \& Raus, Th. (ed.), Euro+Med-Checklist Notulae, 8. Willdenowia 47: 293-309.

El Mokni, R. \& Iamonico, D. 20 I 8a: A new record for the non-native flora of Tunisia, Eclipta prostrata (Ecliptinae, Asteraceae), and a note on the national status of Erigeron bonariensis, Lepidium didymum, and Symphyotrichum squamatum. Flora Mediterranea 28: 145-153.

El Mokni, R. \& Iamonico, D. 20r 8b: Three new records of Senecioneae (Asteraceae) for the allochthonous Tunisian Flora. Flora Mediterranea 28: 385-392.

El Mokni, R. \& Iamonico, D., 2019: Bassia scoparia and Sesuvium portulacastrum, two new naturalized aliens to the Tunisian flora. Flora Mediterranea 29: 191-196.
El Mokni, R. \& Verloove, F. 2019: New records, distribution and taxonomic notes for non-native vascular flora of Tunisia - I. Poaceae. Flora Mediterranea 29: 45-53.

Galasso, G., Conti, F., Peruzzi, L., Ardenghi, N. M. G., Banfi, E., Celesti- Grapow, L., et al. 2018: An updated checklist of the vascular flora alien to Italy. Plant Biosystems 152: 556-592.

Goldblatt, P. 1984: (748) Proposal to conserve 1176 Amaryllis and typification of $A$. belladonna (Amaryllidaceae). Taxon 33: 511-516.

Jarvis, C. E. 1984. Amaryllis belladonna L. - Further comments on lectotypification. Taxon 33: 82-84.

Johnson, S. D. \& Snijman, D. A. 1996: Amaryllis belladonna. Veld \& Flora 82: 70-71.

Linnaeus, C. 1753: Species Plantarum. Holmiae pp. 293.

Meerow, A. W., Van Scheepen, J. \& Dutilh, J. H. A. 1997: Transfers from Amaryllis to Hippeastrum (Amaryllidaceae). Taxon 46: 15-19.

Rouvier, H. 1977: Géologie de l'extrême Nord tunisien: Tectoniques et paléogéographies superposées a' l'extrémité orientale de la Chaîne nord maghrébine. Thesis, Univ. Pierre et Marie Curie, pp. 1-427.

Sealy, J. R. 1939: Amaryllis and Hippeastrum. Bulletin of Miscellaneous Information 2: 49-68.

Snijman, D. A. \& Williamson, G. 1998: Notes on African Plants. Amaryllidaceae, Amaryllideae. A new species of Amaryllis from the Richtersveld, South Africa. Bothalia 28(2): 192-196.

Thiers, B. 2020: Index Herbariorum, a global directory of public herbaria and associated staff. New York Botanical Garden's Virtual Herbarium. http://sweetgum.nybg.org/ih/ (last accessed: 17. 05. 2020)

Tjaden, W. 1981a: Amaryllis belladonna Linn. - An up-to-date summary. Plant Life 37: 21-26.

Tjaden, W. 1981b: Amaryllis belladonna L. Species plantarum 293, 1753. Taxon 30: 294-298.

Tjaden, W. 1979: Amaryllis belladonna and the Guernsey lily: an overlooked clue. Journal of the Society for the Bibliography of Natural History 9: 251-256.

Traub, H. P. 1954: Typification of Amaryllis belladonna L. (1753). Taxon 3: 102-111.

Traub, H. P. 1983. The lectotypification of Amaryllis belladonna L. (1753). Taxon 32: 253-267.

Traub, H. P., \& Moldenke, H. N. 1949: Amaryllidaceae: Tribe Amarylleae. American Plant Life Society, California, Stanford, pp. 1-194.

Uphoff, J. C. T. 1938: The history of nomenclature - Amaryllis belladonna (Linn.) Herb., and Hippeastrum (Herb.). Herbertia 5: 100-111.

Uphoff, J. C. T. 1939: Critical review of Sealy's “Amaryllis and Hippeastrum". Herbertia 6: 163-166.

Véla, E., \& Benhouhou, S. 2007: Evaluation d'un nouveau point chaud de biodiversité végétale dans le Bassin méditerranéen (Afrique du Nord). Comptes Rendus Biologies 33: 589-605.

WCSP. (World Checklist of Selected Plant Families) 2020: World Checklist of Selected Plant Families. Facilitated by the Royal Botanic Gardens, Kew. Published on the Internet, viewed on 30 March 2020, from http://wcsp.science.kew.org/ 